\title{
Archaeological Survey of Areas Proposed for Modification in the Salado Creek Watershed, Bexar County, Texas
}

Thomas R. Hester

Center for Archaeological Research

Follow this and additional works at: https://scholarworks.sfasu.edu/ita

Part of the American Material Culture Commons, Archaeological Anthropology Commons, Environmental Studies Commons, Other American Studies Commons, Other Arts and Humanities Commons, Other History of Art, Architecture, and Archaeology Commons, and the United States History Commons

Tell us how this article helped you.

This Article is brought to you for free and open access by the Center for Regional Heritage Research at SFA ScholarWorks. It has been accepted for inclusion in Index of Texas Archaeology: Open Access Gray Literature from the Lone Star State by an authorized editor of SFA ScholarWorks. For more information, please contact cdsscholarworks@sfasu.edu. 


\section{Archaeological Survey of Areas Proposed for Modification in the Salado Creek}

Watershed, Bexar County, Texas

\section{Creative Commons License}

\section{(c) (1) (8)}

This work is licensed under a Creative Commons Attribution-NonCommercial 4.0 International License 


\section{ARCHAEOLOGICAL SURVEY OF AREAS PROPOSED FOR MODIFICATION IN THE SALADO CREEK WATERSHED, BEXAR COUNTY, TEXAS}

Thomas R. Hester

with the collaboration of Feris Bass, Jr., Anne A. Fox, Thomas C. Kelly

Mary F. Chadderdon and E.S. Harris

with an Appendix by

Thomas C. Kelly

Center for Archaeological Research

The University of Texas at San Antonio

Archaeological Survey Report No. 3

November 1, 1974 
Report Submitted to

THE UNITED STATES DEPARTMENT OF AGRICULTURE SOIL CONSERVATION SERVICE

under terms of an agreement

(307-TX-SCS-75)

Dated September 20, 1974 


\begin{abstract}
In late October, 1974, the Center for Archaeological Research of The University of Texas at San Antonio carried out an archaeological survey of the upper Salado Creek Watershed. Localities slated for the construction of 10 Soil Conservation Service floodwater retarding structures were examined, and 29 prehistoric and historic archaeological sites were found. These cultural resources are described and evaluated. Recommendations are provided for the mitigation of adverse effects on certain of these resources.
\end{abstract}




\section{ACKNOWLEDGEMENTS}

We would like to thank the Soil Conservation

Service for its aid and cooperation during this

project. We are especially grateful to Mr. Logan

Crews (Temple office) and Mr. J. C. Brown (San Antonio

office). 


\section{INTRODUCTION}

During October, 1974, personnel of the Center for Archaeological Research, The University of Texas at San Antonio, carried out archaeological surveys in the watershed of the upper Salado Creek, Bexar County, Texas. The surveys were conducted under an agreement (307-TX-SCS-75) with the U.S. Department of Agriculture Soil Conservation Service (SCS). The SCS proposes to construct a series of floodwater retarding structures along Salado Creek and its tributaries, and the purpose of our surveys was to obtain an inventory of archaeological or historical resources in the areas to be affected. Specifically, our surveys were confined to the areas of 10 proposed floodwater retarding structures, and within each, we examined the localities slated for dam construction, for spillways, borrow pits, and the acreage included in detention and sediment pools. The 10 projects and the acreage involved in each are listed below:

\begin{tabular}{cc} 
Floodwater Retarding Structure No. & Total Acres \\
\cline { 2 - 2 } 3 & 275 \\
5 & 235 \\
6 & 175 \\
7 & 260 \\
9 & 98 \\
10 & 142 \\
11 & 210 \\
$15 B$ & 135 \\
$15-$ Revised & 500 \\
$15 \mathrm{~A}$ & 240 \\
&
\end{tabular}

Total Acreage: $\quad \underline{2,270}$

Standard archaeological survey procedures were utilized during the course of the work. Intensive survey was made of those localities in which construction activities are to be concentrated, and in most other cases, similarly intensive foot surveys were carried out in other parts of the project area.

Prior to initiation of the survey, the site files at the Texas Archeological Research Laboratory (Austin) were examined in order to locate previously recorded site data for the areas involved. We also consulted with Mr. David S. Dibble of the Texas Archeological Survey who had carried out a general reconnaissance of all 15 proposed SCS projects for the National Park Service. Site records and notes resulting from Dibble's work are on file at the offices of the Texas Archeological Survey, Balcones Research Center, Austin, Texas. 
Most of the survey was accomplished by two-person survey teams. As sites were located, designations were assigned and University of Texas at San Antonio site survey forms were filled out. The locations of the sites plotted on USGS topographic maps (7.5 minute series). The site data are on file at the Center for Archaeological Research; duplicates of the survey forms are to be furnished to the Texas Archeological Research Laboratory, where official state site designations will be assigned.

The goals of the survey are listed below. In addition to fulfilling these obligations, survey teams were instructed to record a variety of other types of data, so that the resulting site information could be used in future archaeological studies in the region. The specific survey objectives were:

1. Determine if such archeological resources exist within the area committed to installation of each floodwater retarding structure.

2. If resources are found, record, identify, and appraise the significance of resources.

3. Evaluate the impact of project installation on each resource.

4. Provide and result in recommendations for mitigation of adverse impacts anticipated.

5. Provide estimate of costs required for mitigation (salvage, protection, etc.).

\section{PREVIOUS ARCHAEOLOGICAL RESEARCH}

Over 200 archaeological sites have been reported in Bexar County, but little sustained research into the county's prehistory has been carried out. A summary of earlier work has been published by Fawcett. (1972; see also Woolford, 1935). Also contained in Fawcett's work is a bibliography of published and unpublished reports dealing with Bexar County archaeological research. Of the archaeological sites reported from the county, a high percentage are from areas along or peripheral to the Salado Creek drainage. Among the important sites along Salado Creek are the Rogers site (41 BX 22; Fawcett, 1972), the St. Mary's Hall (or Robinson) site (41 BX 229, being excavated by the Southern Tcxas Archacological Association), the Granberg site (Schuetz 1966), the Granberg II 
site (H. Kohnitz and T. Hester, notes), and a series of sites on the Walker Ranch, reported by Scurlock and Hudson (1973). It is obvious from these and other sites along the drainage, that Salado Creek was an area of intensive aboriginal activity during the prehistoric period.

Among the types of archaeological sites found along the Salado Creek drainage during earlier work are open occupation sites (campsites), burned rock middens, flint quarries and flint workshops, temporary campsites (probably used in hunting and gathering activities), and rockshelters occupied for brief periods (see Fawcett 1972 for additional descriptions of Bexar County sites). There are four major time periods represented by Salado Creek archaeological sites, and these are briefly reviewed here. The Paleo-Indian period (roughly 9200-6000 B.C.) is represented by the occurrence of Folsom and Plainview points, primarily from the St. Mary's Hall site (41 BX 229). The following Archaic period (ca. 6000 B.C. to A.D. 1000) can be divided into three kanor units, Early, Middle, and Late. The Archaic is characterized by a hunting and gathering, semi-nomadic lifeway, and sites contain an abundance of chipped stone artifacts. Among the chipped stone materials are numerous large projectile points (dart points) which undergo changes in shape and form at various time within the Archaic. The Early Archaic is best known from recent excavations at the Granberg II site, while Middle and Late Archaic materials are very common at most occupation sites along the stream and its tributaries. In fact, the highest frequency of datable sites in the watershed can be linked to Middle and Late Archaic habitations. The Late Prehistoric (or Neo-American) era dates approximately A.D. 1000-1600, and is marked by the introduction of the bow and arrow and some limited pottery manufacture. Components from the period are known at a number of sites along the creek. The Historic period is represented by sites of historic Indian groups, and those sites linked to early Anglo-European and Spanish activities. Sites in the latter category are present along Salado Creek. One interesting example is 41 BX 227, with two mid-19th century (?) lime kilns near proposed Floodwater Retarding Structure 15A.

While a number of sites have been previously documented in the Salado Creek Watershed, most archaeological work has been in the form of surface survey. It will require more intensive investigation to elucidate most aspects of the prehistoric lifeway. Archaeological research in the Salado Creek area is made more urgent by the rapid development of the area, particularly the building of housing subdivisions.

Persons interested in the geology, soils, vegetation, and faunal patterns in the Salado Creek area are referred to Fawcett (1972), Hudson and Scurlock (1973) and Taylor et al (1966). 


\section{RESULTS OF THE SURVEY}

During the course of the archaeological survey of the 10 proposed floodwater retarding structures in the Salado Creek Watershed, 29 archaeological sites were found. The locations of the floodwater retarding structures and the recorded archaeological sites have becn plotted in Figures 1-6. Lithic collections were made at most sites and at site 7-1 (41 BX 228), test pits were excavated (see Appendix II). All artifacts have been washed and cataloged by personnel of the Center for Archaeological Research and are presently stored at The University of Texas at San Antonio.

Two of the sites (7-1 and 7-3) are considered of great significance. Because of their importance, they are presently under consideration for placement on the National Register of Historic Places.

In the following pages, each proposed SCS floodwater retarding structure and its environs are discussed. Brief descriptions are provided of sites and artifacts from sites within these areas. 
FLOODWATER RETARI:ING STRUCTURE No. 3

The dam site is located directly north of FM 1604, 1.6 kilometers west of the intersection with Military Highway, in a heavily wooded area of dense cedar and live oak, on the main channel of Salado Creek. The terrain is rough and rocky, with steep cliffs at the bends of the creek. It was not possible to locate the exact position of the proposed dam, but the area was intensively surveyed in the vicinity where it will probably be situated. Very little of the proposed reservoir is habitable land, since most is either within reach of the considerable flooding which takes place after heavy rains, or is too steep and rocky. The one sloping terrace on the east bank just above a horseshoe bend contained nearly all of the recorded sites, plus many intermediate scatterings and occasional random artifacts.

The grass cover was medium in density and did not greatly hinder the survey. Dense brush in the flood plain and inside the horseshoe bend made surveying difficult and may have prevented recording of further sites on the north end of the dam and spillway area.

Site $3-1$

The site is located on a low stream terrace east of a horseshoe bend on Salado Creek. It is at the base of a series of cliffs, .5 kilometers upstream from the proposed dam site. Scattered flake debris a stemed dart point, biface, a scraper and a possible hammerstone were found. These materials occurred in an area 60 meters long (north-south) 
and 45 meters in width. Vertical extent of the deposits at the site is not known. Therefore, it is recommended that a limited testing program be carried out.

Site $3-2$

This site is situated on the same terrace as Site 3-1, approximately 350 meters upstream. Scattered flakes and two biface fragments were found in a circular clearing on the terrace. Although maximum dimensions of the site could not be ascertained, it appears to be about 30 meters in diameter.

No further work is recommended at this site.

Site $3-3$

Due west of Site 3-1 and south of Site 3-2 is a burned rock midden, designated by the survey team as Site 3-3. It is located on a sloping terrace, on the inside of a horseshoe bend on the main channel of Salado Creek. The mound-1ike accumulation of burned rock is about 10 meters in diameter and oval in outline. Maximum height of the midden accumulation is approximately .5 meters above the surrounding ground surface, and occurs near its center. Vegetational patterns in the site vicinity are characterized by a dense growth of cedar.

There is evidence of previous excavation at the site, probably by local relic-collectors. Three four-foot squares and two large 
"potholes" were observed.

It is recommended that limited testing be carried out at the site to determine its depth and the nature of the cultural deposits.

Site 3-4

The site is located on a tributary channel of Salado Creek, near its confluence with the larger stream. Extensive flaking debris and flint cobbles were observed on the surface. The site area is roughly rectangular in outline, 90 meters 1ong (northeast-southwest) and 30 meters wide. Several possible scrapers and representative sample of lithic debris were collected.

No further work is recommended.

Site $3-5$

This site is located in a grassy clearing (surrounded by groves of cedar and live oak) about 450 meters upstream from Site 3-2. The site is small, 45 meters in length (north-south) and 12 meters wide. Flint cobbles and flaking debris were observed, and a representative sample collected.

No further work is recommended. 
FLOODWATER RETAR!:ING STRUCTURE No. 5 .

The projected dam site is located .6 kilometers east of Blanco Road, 2 kilometers south of where Panther Springs Creek crosses that road, north of FM 1604.

The area involved includes a portion of Panther Springs Creek, an intermittent stream which shows potential of extreme flooding cluring heavy rains, and an unnamed tributary with markedly less potential. The land on the east side of the reservoir is terraced, strewn with large limestone boulders and outcrops with little topsoil present, and contains no archaeological sites. The land between the creeks is a grassy, sloping plain dotted with clumps of live oak and cedar, and contains no sites. At its upper end Panther Springs Creek runs between 10 to 20 meter bluffs of limestone, which contain no caves or rockshelters. As one travels south, the west bank changes to a gentle slope, grasscovered and overgrown with cedar near the stream, opening up into clearings between clumps of live oak on the higher elevations. No sites were found on the west side.

At the confluence of the creeks, the land to the southwest is elevated 10 to 15 meters above the stream level in a terrace which contains the only archaeological sites found. Across the creek bed to the south east on the line of the center of the dam is a 25 meter bluff of limestone. On top of this bluff and extending across the area of the spillway is an outcrop of flint cobbles which show evidence of some prehistoric quarrying and workshop activities. 
Site 5-1

This site is located in the area slated for dam construction. It is on a terrace on the northwest bank of Panther Springs Creek, approximately 400 meters southeast of SCS "Steel Pin \#2". Vegetation in the site area consists of cedar, live oak, and grass; nearby, there are several outcrops of flint.

Flint flakes were found scattered over the site in an area approximately 35 meters northeast to southwest and 12 meters in width.

No further work is recommended.

Site $5-2$

Site 5-2 is located in a clearing 25 meters south of Site 5-1, on the same terrace. It is even smaller in area, with a maximum diameter of 15 meters. A number of flint flakes were observed on the site surface, but,as in the case of Site 5-1, there appear to be no buried deposits. No further work is recommended. 
FLOODWATER RETARDING STRUCTURE No.6

The construction site for the floodwater retarding structure is approximately 1.5 kilometers south of Farm Road 1604 and approximately 68 meters east of Blanco Road. The flood basin of this reservoir will cover approximately 94 hectares and extends northward along the course of Panther Springs Creek to a point 900 meters south of FM 1604 and 600 meters east of Blanco Road. The northern half of this proposed project will encompass a portion of the existing Canyon Creek Country Club golf course, an area that has already been extensively modified and therefore disturbed from an archaeological viewpoint.

The western edge of the project area, beginning at a point approximately 1.2. kilometers above the dam site, is a prominent limestone bluff approximately 15 meters in length and immediately adjacent to the main stream bed of Panther Springs Creek. This bluff is covered with moderately heavy vegetation and is marked with a number of eroded areas, some of which several rock shelters. The creek bed is extremely rough and is choked with many limestone boulders and is heavily covered with vegetation.

From the southern edge of the golf course south to the dam site the terrain is heavily vegetated and is covered with many stream rolled boulders.

The vegetation encountered in this flood basin consists of live oak, cedar, white brush, and persimmon and the ground is covered with dense grass which impeded our view of the ground suface over much of the area. 
The survey of this project area was conducted by Feris A. Bass and Thomas Kelly in October, 1974. Due to the nature of the terrain this survey was conducted on foot with the most intensive inspection in the undisturbed areas. Two archaeological sites were identified and recórded.

\section{Site \#6-1}

This site is a rock shelter approximately 4.5 meters wide and 3 meters deep (from front to back). It is located approximately 6 meters above the stream bed just below Lot No.8 on Lariat Drive in Valley View Heights. The front of this rock shelter is screened by live oak and persimmon trees interspersed with heavy grass cover which was dense enough to completely cover the ground and talus slope at the shelter entrance. Because of this cover it was difficult to determine whether the contents of the shelter had been disturbed. A very limited shovel test in the floor of this shelter produced burned rock, flint flakes, and other chipped stone debris. Shells of land snails were also recovered.

It is reconmended that this shelter be further tested to determine the nature and extent of its occupation.

Site \#6-2

This site consists of an extensive scatter of burned rock and flint chipsand extends along the western and southern edges of Canyon Creek Country Club fairway No.7. The site is approximately 180 meters in length, north to south, and 75 meters wide. It lies on the lowest stream terrace along the eastern side of Panther Springs Creek. 
The portion of the site off the fairway, a strip 25 meters wide along the west and 75 meters on the south, is covered with dense grass which impaired our view of the ground. There are also cedar and live oak trees and brush covering this area to the south, at times so thick as to prevent passage through the area. The burned rock scatter appears to be overlain by approximately 10 centimeters of sandy loam containing some gravel.

Specimens collected consisted of a representative sample of burned rock and flint flakes which were scattered over the site surface. There were several possible hearths observed in this area.

It is recommended that limited testing be done to determine the nature and extent of this deposit. 
FLOODWATER RETARDING STRUCTURE No.7

The dam construction site for this project is on Panther Springs Creek, 5.2 kilometers south of FM 1604 and 900 meters east of Blanco Road. The flood basin extends north along Panther Springs Creek to a point 400 meters northwest of Bitters Road. The construction and flood pool site encompasses approximately 118 hectares. The terrain in this project consists of stream terraces bounded on either side by steep hilly slopes. At the widest point the flood pool will be approximately 700 meters at about the north-south mid point in the reservoir.

The northern half of the proposed flood pool is situated on relatively open terrain that has been previously cultivated and which is now covered with a heavy strand of grass, and with numerous clumps of live oak, mesquite, and white brush. Because of the disturbed nature of this portion of the project, coupled with the heavy grass cover, no significant archaeoloigcal materials were discovered.

The southem half of the project is of a completely different character. The vegetation covering this area, composed of live oak, cedar, persimmon; mesquite, and white brush is extremely dense to the point that the majority of this area could only be penetrated with the aid of a machete; even then the grass cover was so thick that ground inspection could only be accomplished with difficulty.

The survey of this project was initiated by Feris A. Bass and Thomas Kelly on September 26th and 28th, 1974, with follow-up surveys 
on October 5,6,12,13 and 15, 1974. The surveys were conducted on foot and, because of the heavy vegetation, were confined primarily to existing roadways, clearings and natural open areas, although attempts were made to penetrate the heavy vegetation in order to make a more complete evaluation.

This area had been previously surveyed (Scurlock and Hudson, 1973) and numerous archaeological sites have been recorded in the area (see Appendix I). These earlier investigations were hampered, as we were, by the heavy vegetation. This factor perhaps accounts for the great number of sites identified by them as they approached what we found to be large, single sites from a number of different directions. We have evaluated these previously reported sites and have confirmed their existence, but have included in the report only those we feel are significant to the survey. The existing site designations have been used in identifying our findings, but we have, in most cases, expanded the site areas originally reported. 
Site 7-1 (41 BX 228)

This site is located directly beneath the eastern arm of the proposed dam and extends approximately 120 meters from the centerline of the dam in a southerly direction for the full length of the dam. The site encompasses an area of approximately $300 \times 120$ meters.

This site was previously identified by Scurlock and Hudson (1973). However, we feel that perhaps due to the restrictive vegetative environment, its full scope was not realized at that tine. We have therefore increased the size of the site from the original estimate of ca. 200 square meters to approximately 36,000 square meters.

As indicated, the site is covered with extremely dense vegetation which, over much of the area, defies penetration. However, by approaching from several directions it was possible to gain a better estimate of its extent.

During the 1973 investigation, a shallow test pit was dug approximately 100 meters east of Panther Springs Creek almost on the centerline of the proposed dam. This test produced 12 Archaic and Neoamerican projectile points in the top 20 centimeters of deposit. During our investigation this test pit was extended to 60 centimeters in depth, and a second pit ( 1.5 meters square) was sunk to the same depth. Forty additional artifacts were recovered, along with a great quantity of occupational debris (see Appendix \#2).

Due to the extremely rich nature of this site it is recommended that a larger and more representative excavation be conducted in order to develop a clearer concept of the nature and age of the site. 
Site $7-2$

This site is exposed in the bed of the ranch road running from the old ranch headquarters to the vicinity of Site 7-3. Scattered flakes and burned rock were observed in an area roughly 50 meters east of Panther Spring Creek. Since much of the site appears to be buried, and because of heavy vegetation, we were unable to determin the approximate horizontal extent of the site. No further work is recommended.

Site $7-3(4 I$ BX 180)

This site is a collection of limestone ruins located 144 meters and $275^{\circ}$ west of the windmill on the hill at the northeast terminus of the proposed dam. It is on the upper stream terrace approximately 40 meters north of the ranch road from the windmill to the old ranch house on Panther Spring Creek.

These ruins include at least two multi-room structures and several out buildings.

The area is heavily overgrown with brush and grass, with many mesquite, live oak and persimmon trees in the vicinity (vegetation is so dense that visibility in any direction was Iimited to not more than 10 meters).

There has been previous work at these ruins but because of budgetary limitations and other constraints, they have not yet been conclusive and many questions still remain to be answered. There has been speculation that these buildings date from Spanish Colonial times. No evidence has been found to support this belief; we suspect the ruins date from the mid-19th Century. 
It is recommended that the ar i be cleared, the ruins more thoroughly excavated and a more exhaustive search of historical data be instituted to resolve questions relative to the origin, use and importance of this complex.

Site $7-4$ (41 BX 197)

This site is characterized by an extremely heavy concentration of worked flint and burned rock, indicating a possible occupation area. This site extends along the west bank of Panther Springs Creek from the western arm of the proposed dam to a point approximately 500 meters upstream, and includes the large cultivated field north of the dam site, as well as the barns and farm buildings on further to the north. The width of the site extends back from Panther Springs Creek approximately 90 meters.

The large cultivated field, which occupies the major portion of this site, has been repeatedly plowed and, according to Mr. Walker, a former owner, extensively collected by amateurs for many years. It is presently covered with a heavy stand of grass which precluded a close examination of the surface. Heavy vegetation also covers the other portions of this site.

Even with these deterents it was possible to observe a heavy concentration of archaeological materials. .

Though the area has been extensively disturbed by plowing, cattle grazing, and ranch operations, and, since there is no evidence of previous scientific archaeological exploration of the area, it is recommended that several test pits be opened to determine the depth and character of the deposits that might underlie the disturbed surface 
Site $\# 7-5$

This site lies on the east bank of Panther Springs Creek adjacent to a permanent waterhole and just opposite to the old Walker Ranch headquarters. The area encompassed by the site would include a collection of small sites previously reported as 41 BX 217, 41 BX 191, and 41 BX 192 (Scurlock and Hudson, 1973). The horizontal extent of the site is in excess of 15,000 square meters, extending approximately 500 meters along the ranch road paralleling Panther Spring Creek to a point 200 meters north of the permanent waterhole. The average width of the site is approximately 300 meters.

This site, as in the case of the others reported here, is covered with extremely dense vegetation including live oak, mesquite, white brush, cedar, and grass.

Archaeological materials found at this site include a heavy surface scatter of flint flakes and burned rock, as well as a number of hearths, one of which was excavated during the survey. Artifacts collected include three dart points, several flint cores, bifacial rough outs, and point preforms.

It is recommended that a more extensive survey be conducted to determine the true extent of this occupation area, a more accurate appraisal of the number and character of the hearths, and excavation of three or four test pits to permit a better evaluation of sub-surface materials. 
Other Sites

Several other small sites were identified which closely coincided with those found during the earlier Walker Ranch survey (Scurlock and Hudson, 1973). However, these are not considered to be individually significant given the purposes of the present survey. See Appendix I for a listing of these sites. 
FLOODWATER RETAPDING STRUCTURE No.9

The dam site is located 50 meters west of US Highway 281 , approximately 13 kilometers north of Loop 410.

The area includes a section of Mud Creek, an intermittent stream apparently capable of great velocity at flood stage. Areas of steep cliffs on the east side at the northern end and on the west from the mid-point on south contain no caves or rock shelters. None of the densely forested Iand on the west bank contains archaeological sites, but there is an area just south of the mid-section which contains an outcropping of flint cobbles which may have been quarried.

The land from the mid-point south on the east side of the creek is sloping, terraced grassland between dense thickets of live oak and cedar. No archaeological sites are present except for a scattering of flint debris on the east terrace at the approximate location of the center of the spillway.

Grass cover is moderate to thick, but flint is readily observed in the open areas. The survey was intensive except in the upper reaches of the reservoir where dense brush and rough terrain hampered more thorough work.

\section{Site $9-1$}

The site is located in the center of the proposed spillway, on a low terrace midway between the proposed SCS dam site and a fence line - to the south. The site appears to be roughly circular in outline, with a 
maximum diameter of 45 meters. It is interesting to note that the site area appears to have been cleared of large stones, while the surrounding vicinity is strewn with rock. Flint flakes and cores were observed, and all materials were collected.

There appears to be no depth to the cultural deposit at Site 9-1 and no further work is recommended. 
FLOODWATER RETARDIY: STRUCTURE No.10

The dam construction site for this project is approximately 250 meters northwest of Jones-Maltsberger Road along the course of Mud Creek. The flood pool will extend along Mud Creek west and north across FM 1604 to a point approximately 200 meters north of that road. The total area of this project is approximately 61.5 hectares.

The terrain in this reservoir is extremely rugged and consists primarily of the stream bed filled with a heavy concentration of large boulders, and with a dense growth of live oak, cedar, mesquite, and white brush. The edges of this stream channel are steep bluffs in some instances rising in excess of 20 meters vertically above the stream bed.

This project was surveyed by Feris A. Bass and Thomas Kelly in October, 1974. Because of the extremely rough terrain involved, the survey was conducted entirely on foot. Only three small sites were identified on this survey.

Site 10-1

This site is on a small stream terrace approximately 200 meters south of FM 1604 on the west side of Mud Creek. The site area is characterized by a thin topsoil, covered with scrub oak and prickly pear. Material recovered consisted of cores, knapping debris, and one oval shaped uniface. Further work at this locale is not necessary. 
Site 10-2

This site is located on a flat terrace along the south side of Mud Creek approximately 800 meters west of the intersection of Mud Creek with Jones-Maltsberger Road. The site is opposite a large house on a bluff across Mud Creek. The site area is covered with grass and scrub oak; there is a thin layer of topsoil overlying limestone bedrock.

Archaeological materials collected or observed consisted of flint flakes, one biface fragment, a scraper, and a core. Given the sparcity of materials and the nature of the terrain, we suggest that no further work be done at this site.

Site $10-3$

This site is a small rockshelter located in the wall of the bluff on the north side of Mud Creek approximately 400 meters from the intersection of Mud Creek with Jones-Maltsburger Road. The shelter is approximately 3.5 meters above the stream bed and is 4 meters wide at the mouth and extends back into the cliff approximately 3 meters.

The deposit in the shelter is a fine occupational fill with some limestone spall in evidence. The depth of the deposit is approximately 30 centimeters and a small shovel test indicates definite stratification of the deposit. 
From the small test trench we recovered a number of flint flakes, a deer vertebra, rodent bones and some burned rock.

It is recommended that the shelter be excavated to determine the nature and date of its occupation. 
FLOODIVATER RLTARDIIG STRUCTURE: No.11

The dam construction site for this project is approximately 150 meters north of FM 1604 at intersection with Elm Creek. The dam will extend approximately 300 meters east and west of Elm Creek. Fifty meters north of the proposed dam Elm Creek divides into two tributaries, West Elm Creek and East Elm Creek. West Elm Creek extends to the west and north approximately 1.8 kilometers. East Elm Creek extends north 400 meters, then southeast for 700 meters turning north for another 700 meters and then west for 500 meters to the end of the flood pool. The total area contained in this project is 95 hectares.

These stream courses are extremely rough, containing large boulders which almost precludes passage along the stream bed. Interspersed among the boulders are oaks, cedars, and some white brush. Along the stream terraces, which from time to time widen into relatively flat and level plains, there are occasional open places in the heavy vegetation. Along the West Elm Creek it was noted that this type of terrain usually revealed prehistoric occupation sites.

The survey of this reservoir site was conducted by Feris A. Bass and Thomas Kelly in late September, 1974. Because of the ruggedness of the terrain the survey was conducted entirely on foot. Six sites were located.

Site 11-1

This site borders Elm Creek along the east and east Elm Creek along its southern edge. The site occupies the slopes and top of a 
high ridge that parallels FM 1604 and is estimated to be .8 kilometers long and .12 kilometers wide. The site is crossed by a highline right-of-way which has been cleared. The balance of the site is covered with grass and clumps of live oak and cedar trees. The topsoil is relatively thin and there are numerous limestone and flint outcrops.

The top of the ridge, which is outside of the flood pool of this project, is heavily covered with worked flint which declines in density toward the bottom of the slopes. There is indication, however, that deposits may have been buried by colluvium on the terraces bordering Elm Creek. A few test pits could be sunk on these terraces to determine the actual extent of this large site. Artifacts recovered reflect workshop activites and include large cores, large biface preforms, and an extensive array of debitage. This site would encompass part of the previously reported 41 BX 68 (on file, Texas Archeological Research Laboratory, Austin).

Site $11-2$

This site is located on the north edge of west Elm Creek and east Elm Creek at their confluence, and is situated on a low terrace between the two streams. The site is a small flint-chipping station approximately 18 meters in diameter, and contains a light concentration of large flint flakes and core material. 
The site is covered with cedar, scrub oak, mesquite, brush, and short grass.

No further work is recommended at the site.

Site 11-3

This site is located on a stream terrace on the south side of west Elm Creek approximately 200 meters north of a steel transmission tower.

The site is covered with a 30 centimeter layer of alluvial deposit and has a scattering of burned rock and flint chips, and could contain buried materials. The true nature and extent of the surface materials was difficult to determine because of the heavy grass and vegetation cover (consisting of oak, cedar and mesquite). However, the horizontal extent of the site appears to be 40 meters by 150 meters.

Because this site is located in one of the borrow areas for the dam construction, it is recommended that a further surface survey and test pitting be conducted.

Site $11-4$

This site is located approximately 150 meters north and east of Site 11-3 on a terrace on the east side of West Elm Creek. The site appears to be a small quarry and chipping station, 30 meters by 60 meters in area. The site surface exhibits a moderately heavy scattering of flakes, exhausted cores, and burned rocks. Further surface survey and controlled collection would be desirable. 
Site 11-5

This site is located on the stream terrace between West Elm Creek and a ridge that projects in toward the confluence of East and West E1m Creeks (approximately 650 meters north of FM 1604).

The site is covered with heavy vegetation which severely restricted the view of the ground surface. The type of vegetation encountered was grass, mesquite, cedar and scrub oak. The topsoil is a sandy loam overlying limestone bedrock.

The site appears to be a small, temporary occupation area and yielded flint flakes and burned rock. There appeared to be a possible hearth. No further work is deemed necessary.

\section{Site 11-6}

This site covers an area of approximately 15 meters by 50 meters and is located 400 meters south of the transmission lines on the ridge dividing East and West E1m Creeks.

This site is covered with heavy vegetation, oak, mesquite, cedar, and grass. The soil is sandy loam 20 to 30 centimeters deep with occasional limestone outcrops.

Due to heavy vegetation it was difficult to make a valid assessment of the true character of this site and since it occupies a major borrow area for the dam construction, it is recommended that another survey be conducted when ground visibility would be better. Test pitting would also be beneficial. 
FLOODWATER RETARD 2 NG STRUCTURE NO.13-B

The dam site for this project is approximately 600 meters northeast of the intersection of FM 1604 and Bulverde Road. The dam will impound the run off of a tributary of Elm Waterhole Creek.

The area covered by the flood pool is approximately 59 hectares, and will have two arms, one extending to the north and west approximately 1,200 meters, and the other to the east and north approximately 1,000 meters.

The terrain encompassed by this reservoir area is covered with moderately heavy grass witn oak, cedar, mesquite and persimmon groves that are fairly dense along the stream courses.

The topsoil is thin and overlies a limestone base. There are numerous stone outcroppings in the area.

The survey of this reservoir and dam site was conducted on foot by Dr. Thomas R. Hester and Feris A. Bass in late September, 1974. No archaeological remains were discovered and there is no need for further work in this project area. 
FLOODWATER RETARDING ST'RUCTURE No. 15-A

The project area is located on Lorenz Creek, west of Jones-Maltzberger road. The proposed dam site is roughly 450 meters west of the spot where Lorenz Creek crosses Jones-Matzberger road. In conversations with J.C. Brown and Logan Crews, it was established that there was little, if any, likelihood, that 15-A would ever be built. We decided that the allotted survey time would be better spent in other areas for which floodwater retarding structures are definitely slated, and therefore, only a brief survey of 15-A was carried out. Much of the 15-A area has been greatly modified by several housing developments. Where natural vegetation remains, there was a dense growth of white brush and a heavy grass cover at the time of the survey.

There are several archaeological sites in the vicinity. Site 41 BX 227 lies outside of, and to the north, of the proposed project area. It is a historic lime kiln which has been investigated by Anne Fox (Witte Museum), assisted by members of the Southern Texas Archaeclogical Association. Another site is located just west of 1 BX 227, along Heimer Road and also outside the project area. This was a major prehistoric quarry-workshop, with numerous flint-working loci (notes on file, University of Texas at San Antonio). However, most of the site has been destroyed by subdivision development. During our field inspection, yet another large quarry-workship (site 15A-1) was observed about 400 meters south of the intersection of Lockhil1-Selma and Jones-Maltzberger roads. On the site surface are large cores, flakes, and one intact hearth. Debris 
is exposed on both sides of Jones-Maltzberger road, east of the proposed dam site.

Unless plans for this project are revived, no further work is recommended. 
FLOODWATER RETAIUING STRUCTURE NO. 15

Revised

The proposed dam site is located on Mud Creek just above its confluence with Salado Creek and within the Northeast Preserve Park (City of San Antonio) about 900 meters north of Starcrest Drive.

Most of the area within the proposed reservoir pool was surveyed by Fox (1973). Sites reported at that time will all fall on the outer edge of the floodpool or just beyond. Additional survey work has disclosed more chipping debris on the same terrace to the south of the first two sites, but all just above the reservoir edge. A survey of the additional land upstream added by the revision of plans for the dam failed to show any additional sites.

Site $15-1$

The site is located on a terrace east of Mud Creek and 60 meters south of Site 15-3 (41 BX 173; see below). It occupies an opening in otherwise dense vegetation, consisting of live oak, cedar, persimmon, and other shrubs.

Within a crescent-shaped area 75 meters long and 30 meters wide, flint cobbles, large flakes and other lithic debris were collected. The site appears to represent a chipping station.

No further work is recommended.

Site $15-2$ (41 BX 172)

- This site has been previously reported by Fox (1973). It lies on 
a terrace east of Mud Creek or Bee Tree Drive. Occupational remains include burned rock and flint debris in an area approximately 15 meters in diameter. Fox reports a fragment of a Pandora dart point, a biface fragment, a scraper, and flakes from the site.

No further work is recommended.

Site 15-3 (41 BX 173)

Fox (1973) reports this site as located on a terrace 150 meters south of 41 BX 172 (Site 15-2). She found scattered flakes and 1ithic tools in an area 30 meters in diameter.

No further work is recommended.

Site 15-4 (41 BX 174)

The site is located on a ridge in the northeast corner of the Northeast Preserve Park. It is an extensive site, attributable mainly to quarrying and flint-working activities. Limits of the site have not been determined. A large amount of chipped stone debris was observed.

It is recommended that additional survey and controlled collecting be carried out at the site. 


\section{SUMMARY AND RECOMMENDATIONS}

During October, 1974, the Center for Archaeological Research at The University of Texas at San Antonio carried out an archaeological survey of portions of the Salado Creek Watershed, Bexar County, Texas. The ten localities inspected were slated for development as SCS floodwater retarding structures. A total of 2,270 acres was examined. The survey led to the documentation of 28 prehistoric and historic archaeological sites.

We have reviewed the data obtained during the survey and appraised the significance of each of the sites. The following kinds of sites were recorded:

a] major occupation (I arge campsites): 3-3, 7-1, 7-4, 7-5

b] temporary occupation (short-term campsites): 3-1, 3-2, 3-4, $3-5,5-1,5-2,6-1,9-1,10-1,10-2,10-3,11-3,11-5$, $15-2,15-3$

c] flint quarries and workshops: 11-1, 11-2, 11-4, 15-1, 15-4, 15A-1

d] historic ruin: 7-3

e] function uncertain: 6-2, 7-2, 11-6

These sites were situated in the following topographic situations:

a] terrace sites (usually lowest terrace): 3-1, 3-2, 3-3, 3-5, $5-1,5-2,6-2,7-2,7-4,9-1,10-1,10-2,11-2,11-3,11-4$, $11-5,11-6,15-1,15-2,15-3,15 \mathrm{~A}-1$ 
b] floodplain: $3-4$

c] stream bank: 7-1, 7-5

d] upper/high terrace: 7-3

e] uplands: $11-1,15-4$

f] rockshelter (occupation under an overhang in cliff face): $6-1,10-3$

All of these kinds of sites, occurring in similar topographic locales, have been previously documented in the Bexar County area. Most of the occurrences are temporary campsites, perhaps used in hunting and gathering endeavors (or for some other specific, shortterm function), characterized by a scattering of lithic debris and thin cultural deposits.

of particular significance are the major occupation sites and the historic ruin listed above. Major occupation sites are not uncommon in Bexar County, but few have ever been investigated. Most have suffered from city expansion, being destroyed or covered over by housing subdivisions. This is extremely unfortunate, as these kinds of sites can provide archaeologists with a wealth of information on prehistoric development in the region. Of these major occupation sites, site 7-1 appears destined to be badly damaged by the construction of the dam in project 7 . We consider this large site to be of such significance that we have undertaken to nominate it to the National Register of llistoric Places. Before the dam is constructed in project 7, we strongly 
recommend mitigation of this damage through a program of excavation at the site. A cost estimate for this investigation is presented below. Limited test excavations are also recommended for major occupation sites $3-3,7-4$, and 7-5.

The historic ruin (7-3) on the old Walker Ranch in the project 7 area should also be more thoroughly investigated, as it seems destined for destruction by borrow pit activities. This min has been the focus of much interest in Bexar County. Excavations have been done there by Trinity University (San Antonio) and the Texas Historical Commission (Scurlock and Hudson 1973), but none of this work has been either extensive or definitive. There are those who think that this ruin represents an early Spanish structure, while other interested persons believe it dates to the mid-19th century. In either case, it is an important cultural resource and should be properly studied before it is destroyed. This site has also been nominated to the National Register of Historic Places and therefore we recommend a program of excavation, mapping, historical research, and the preparation of detailed architectural plans.

It is also recommended that excavations be carried out at the two rockshelter sites $(6-1,10-3)$. Both are small and would take little time to properly study. Such sites have not been scientifically investigated in Bexar County; instead, most have been pillaged by relic-collectors and vandals. The excavation of these sites is combined in our attached cost estimate for a program of site testing 
(the rockshelters and sites $3-3,7-4$, and 7-5 mentioned above) and controlled surface collecting (at several temporary campsites and quarryworkshops).

In concluding, we further recommend that appropriate agencies Coffice of the State Archaeologist, Texas Historical Commission, Center for Archaeological Research, etc.), be notified should historic or prehistoric materials be encountered during the construction process at any of these 10 proposed floodwater retarding structures. 
COST ESTIMATES FOR MITIGATION AT SITE 7-1 (41 BX 228)

Site 41 BX 228 is a large and deep site, slated to be disturbed by construction of the dam site at project 7 . In order to properly sample this large site, a 30-day program of excavations is strongly recommended. This program will result in data on site content, faunal remains (diet), and prehistoric activities in the site area.

The following is an estimate only; this is not an official budgetary proposal. No allowance has been made for rising costs due to inflation. Estimates are to the nearest dollar.

\section{SALARIES AND WAGES}

Supervising archaeologist

(Dr. Thomas R. Hester)

Field archaeologist (Research Associate) @ $\$ 30.40$ per day for 30 days

912.00

Technical Staff Assistant III

a $\$ 25.68$ per day for 30 days

770.00

Four (4) laborers @ $\$ 17.60$ per day for 30 days

$2,112.00$

Laboratory worker (Technical Staff

Assistant III, @ $\$ 25.68$ per day

for 30 days)

770.00

Laboratory worker (Technical Staff

Assistant III, a $\$ 25.68$ per day

for 30 days)

770.00

- Preparation of report by Field Archaeologist (Research Associate, (a) $\$ 30.40$ per day for 30 days)

912.00

Staff benefits (at $6 \%$ of SEW)

374.00

MAINTENANCE, OPERATION AND EQUIPMENT

Expendable supplies and equipment (includes crafting and other aspects of report preparation)

600.00 
Report publication

$\$ \quad 1,200.00$

Travel

400.00

Rental of heavy equipment

(backhoe)

300.00

CONSULTANTS

Photographic consultant

200.00

Surveying and mapping consultant

200.00

INDIRECT COST

At $27 \%$ of S\&W

$1,686.00$

TOTAL COST ESTIMATE: $\$ 11,206.00$ 
Site 7-3 is a historic ruin in the area of Floodwater Retarding Structure No. 7. Based on data supplied by the SCS and the contractor, the locality now occupied by the ruin will be used as a borrow pit during dam construction. Therefore, it is highly recommended that a program of excavation, historical research, and architectural study be carried out. Fifteen days of field work are proposed.

The following is an estimate only; this is not an official budgetary proposal. No allowance has been made for rising costs due to inflation. Estimates are to the nearest dollar.

\section{SALARIES AND WAGES}

Supervising archaeologist

(Dr. Thomas R. Hester)

$\$ \quad-0-$

Field archaeologist (Research

Associate, @ $\$ 30.40$ per day

for 15 days)

456.00

Technical Staff Assistant III @

$\$ 25.68$ per day for 15 days

385.00

Three (3) laborers e $\$ 17.60$ per day

for 15 days

792.00

Technical Staff Assistant III, in charge of architectural survey

$\$ 25.68$ per day for 15 days

385.00

Laboratory worker (Technical Staff

Assistant III, @ $\$ 25.68$ per day for 15

days)

385.00

Laboratory worker (Technical Staff

Assistant III, e $\$ 25.68$ per day for 15

days)

385.00

Preparation of report by Field

Archaeologist, @ $\$ 30.40$ per day for

15 days

912.00

Staff benefits (at $6 \%$ of S\&W)

222.00 
MAINTENANCE, OPERATION AND EQUIPMENT

Expendable supplies and equipment

(includes drafting and other aspects of report preparation)

300.00

Publication of report

500.00

Trave 1

200.00

\section{CONSULTANTS}

Historical research consultant

500.00

Phatographic consultant

150.00

Surveying and mapping consultant

200.00

INDIRECT COST

At $27 \%$ of $S \& W$

999.00

TOTAL COST ESTIMATE:\$

$6,771.00$ 
A number of sites, including major occupation sites, temporary campsites, flint quarries and workshops, and rockshelters, will be affected by construction of the 10 SCS floodwater retarding structures. To mitigate the adverse effects of the construction program, we recommend a 10-day program of test excavation and controlled surface collection at several sites, including $3-3,7-4,7-5,6-1$, and $10-3$.

The following is an estimate only; this is not an official budgetary proposa1. No allowance has been made for rising costs due to inflation. Estimates are to the nearest dollar.

SALARIES AND WAGES

Supervising archaeologist

(Dr. Thomas R. Hester)

Field archaeologist (Research

Associate) \& $\$ 30.40$ per day for

10 days

304.00

Technical Staff Assistant II @

$\$ 25.68$ per day for 10 days

257.00

Two (2) laborers at $\$ 17.60$ per day

for 10 days

352.00

Laboratory worder (Technical Staff

Assistant III, a $\$ 25.68$ per day for

10 days)

257.00

Preparation of report by Field

Archaeologist (Research Associate

(e) $\$ 30.40$ for 10 days)

304.00

Staff Benefits (at 6\% of S\&W)

88.00

MAINTENANCE, OPERATION AND EQUIPMENT

Expendable supplies and equipment (includes drafting and other aspects or report preparation)

150.00

Report publication

150.00 


\author{
CONSULTANTS \\ Photographic consultant \\ $\$ \quad 100.00$ \\ INDIRECT COSTS \\ At $27 \%$ of $\mathrm{S} \xi \mathrm{W}$ \\ 398.00
}

TOTAL COST ESTIMATE: \$2,560.00 
Fig. 1

Locations of the 10 Proposed Floodwater

Retarding Structures in the Salado Creek Watershed 
This page has been

redacted because it

contains restricted

information. 
(

Fig. 2

Locations of Sites in Floodwater Retarding

Structure No. 3 
Fig. 3

Locations of Sites in Floodwater Retarding

Structures Nos. 5 and 9 
This page has been

redacted because it

contains restricted

information. 
This page has been

redacted because it

contains restricted

information. 
Fig. 4

Locations of Sites in Floodwater Retarding

Structures Nos. 6 and 7 
This page has been

redacted because it

contains restricted

information. 
Fig. 5

Locations of Sites in Floodwater Retarding

Structures Nos. 10 and 11 
This page has been

redacted because it

contains restricted

information. 
This page has been

redacted because it

contains restricted

information. 
Fig. 6

Locations of Sites in Floodwater Retarding

Structure No. 15 - revised 


\section{APPENDIX I}

CONCORDANCE TABLE FOR SITES

IN THE AREA OF FLOODWATER RETARDING STRUCTURE NO.7

UTSA Field Designations

$7-1$

$7-2$

$7-3$

$7-4$

$7-5$

Small sites examined but no new data recorded
Scurlock and Hudson, 1973

41 BX 222, 223, and 228

41 BX 197

$4 I$ BX 180

41 BX 184

41 BX 191, 192, and 217

41 BX 182, 185, 186, 187, $188,198,199,200,201$, 219,220 , and 221

(locations of these sites are plotted in Fig. 2 of

Scurlock and Hudson 1973) 
APPENDIX II

Notes on Test Excavations at Site 41 BX 228 (Panther Springs Site)

Thomas C. Kelly

Site 41 BX 228 (UTSA Survey No. 7-1) was originally reported by W. R. Hudson and W. Lynn in a site survey form filed with the Texas Archaeological Research Laboratory (Austin) in November, 1973. A smal1 test pit was dug by them, and extended to a depth of $20 \mathrm{~cm}$. below the surface. Twelve Neo-American and Archaic projectile points, bison (?) bone, lithic debris, and other occupational remains were found. They recommended further excavations at the site.

This brief report describes additional testing at the site by personnel of the Center for Archaeological Research (The University of Texas at San Atnonio) as part of an archaeological survey of the area (Floodwater Retarding Structure No. 7) for the USDA Soil Conservation Service.

\section{Site Description}

The site is on the east side of Panther Creek, approximately .6 kilometers southeast of the old Walker Ranch headquarters. The northern portion of the site will lie under the proposed eastem section of the dam site.

A comparatively flat terrace rises abruptly approximately 4.5 meters above the stream bed and consists of about .6 meters of Lewis Silty Clay over bedded limestone rocks and river gravels. A natural section is visible in the bank about 90 meters downstream (south) from the site. Flint artifacts and burned rocks on the surface indicate 
that the site probably covers the entire 810' contour level (on the USGS Castle Hills) that makes almost a circle of the area. Further testing is needed to determine the exact limits of the site.

The site area is heavily overgrown with oak, mesquite, white brush, hackberry, juniper, elm, prickly pear, and a variety of weeds and grasses. There is standing water 140 meters upstream, and the permanent water in front of the old Walker ranch house is about 650 meters upstream. The stream bed opposite the site is dry and is a jumble of lime-coated boulders and cobbles Either the stream bed or the banks below the site could have been ready sources of the burnt limestone (hearth stones) found at all levels in the site as well as the chert used in making the 1ithic artifacts.

\section{$\underline{\text { Excavation Procedures }}$}

The original test pit dug by Hudson and Lynn in 1973 was re-located and labeled Pit 1. Pit 2 was laid out to the west, separated from Pit 1 by a 30 centimeter balk.

Pit 1 was first cleaned of the old fill, enlarged to a 1.5 meter square, and excavated to a depth of 60 centimeters. Only levels 3 and 4 (30-45 centimeters and 45-60 centimeters) were undisturbed by the earlier excavation. In enlarging the pit, several artifacts were found in situ in the pit walls and were assigned to their specific levels.

Pit 2 was also a 1.5 meter square, dug (by trowel) in 15 centimeter arbitrary levels, from ground surface to a depth of 75 centimeters. 
The excavated deposits were passed through fine mesh screen and all recovered materials were bagged according to arbitrary levels. Artifacts, field notes, profiles, and other documentation are on file with the Center for Archaeological Research.

\section{Nature of the Deposits}

There is no discernable stratigraphy in the almost black Lewis Silty Clay soil through the first three levels (to a depth of 45 centimeters). Below 45 centimeters the soil rapidly changes from black to an orange gravelly soil at 60 centimeters, and, by 75 centimeters, sterile white limestone cobbles and river gravels soil are encountered. For all practical purposes, the two test pits reach culturally sterile deposits at 60 centimeters. One exception is an unfinished (?) dart point found on the screen and derived from the last 15 centimeters level in Pit 2 (6075 centimeters).

An unusually heavy concentration of burned rock was found in both pits between 45 and 60 centimeters and one probable hearth was noted in Pit 1 at this level.

Shells of land snails (Rabdotus) were plenticu throughout tha first

four levels but no discernable patterns or concentrations observed. Bone fragments (generally of deer), cut and broken, were scattered throughout and were generally in very poor state of preservation. Several possible bone tools were found. 
Artifacts

Ten Neo-American arrow points (Perdiz and Edwards types) were found, all but two in the first two levels and none in the fourth level. Thirty Middle to Late Archaic dart points (Pedernales, Montel1, Castroville, and Frio, in order of their frequency) were found in all levels, but predominated in the third and fourth levels of the two pits. Other specimens included a burin, finely chipped unifacial tools (scrapers), both thin and thick bifaces, choppers, exhausted cores, grinding stones, and thousands of flakes. These specimens from Pits 1 and 2 are presently under analysis.

$\rightarrow$

\section{Conclusions}

The two test pits indicate that the deposits at Site 41 BX 228 are extremely rich in artifactual remains. Although the deposits extend to a depth of less than one meter in the test pit area, it appears that considerably thicker deposits lie in the portion of the site immediately to the south. The site covers a very large area, perhaps as much as 36,000 square meters, and from surface indications, it seems likely that buried deposits are to be found in most parts.

\section{Acknowledgments}

The voluntary efforts of the following UTSA students and their families are appreciated: Ruth Conners, Lynn Highley, P.J. Magness, and Jac, Allen and Cherry Jacquier. . 
Figures 7-9

Illustrations of Selected Projectile Points

from Test Excavations at Site 7-1 (4I BX 22S) 

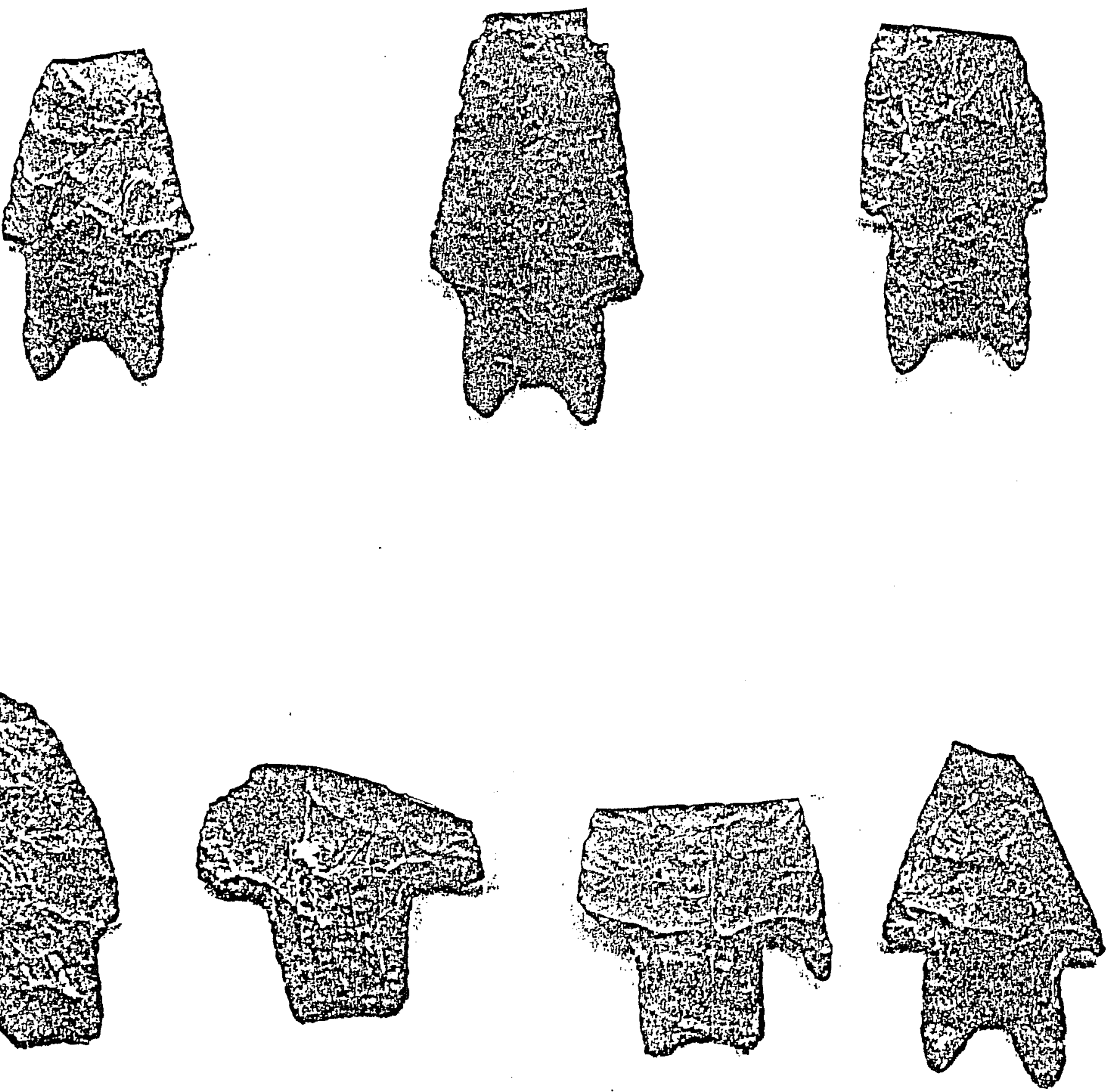

Fig. 7 

APPENDIX III

Conversion Factors

Multiply

by

To Obtain

Centimeters

.3937

Inches

Meters

3.2808

Feet

Meters

1.0936

Yards

Kilometers

.6214

Miles

Square Meters

10.764

Square Feet

Square Meters

1.196

Square Yards

Hectares

2.471

Acres 
Fawcett, W. B., Jr.

1972 The Prehistory of Bexar County: A Study of Previous Work in South Central Texas. Bulletin, Lower Plains Archeological Society 2 (for 1971): 23-44.

Fox, A. A.

1975 An Archeological Survey of the Northeast Preserve and $J$ Street Park, San Antonio, Texas. Report submitted to the Texas Antiquities Committec.

Schuetz, M. K.

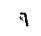

1966 The Granberg Site: An Archaic Indian Habitation in Bexar County, Texas. Witte Museum Studies 1.

Scurlock, D. and W. R. Hudson, Jr.

1973 An Archeological Investigation of Walker Ranch. Texas Historical Comnission, Austin.

Taylor, F. B., et al

1962 Soil Survey of Bexar County, Texas. U.S. Department of Agriculture, Soil Conservation Service, Series 1962,12 .

Woolford, S. W.

1935 Types of Archeological Sites in Bexar County, Texas. Witte Museum, Archeological Bulletin 4. 